\title{
SOCS1 silencing can break high-dose dendritic cell immunotherapy-induced immune tolerance
}

\author{
QINGHAI HU ${ }^{1}$, XIA QIN ${ }^{1}$, GAOCHAO QIAN ${ }^{1}$, SHAN JIANG ${ }^{1}$, HAIYAN LI ${ }^{1}$, \\ MIN JIANG ${ }^{1,2}$, XIAOYAN LI ${ }^{1}$, SI-YI CHEN ${ }^{3}$ and YING QIN ZANG ${ }^{1,2}$ \\ ${ }^{1}$ Shanghai Jiao Tong University Medical School, Shanghai Institute of Immunology, 280 South Chongqin Road, \\ Shanghai 200025; ${ }^{2}$ Institute of Nutritional Sciences, Shanghai Institutes of Biological Sciences, \\ Chinese Academy of Sciences, 294 Taiyuan Road, Shanghai 200031, P.R. China; ${ }^{3}$ Center for Cell \\ and Gene Therapy, Baylor College of Medicine, One Baylor Plaza, Houston, TX 77030, USA
}

Received November 5, 2007; Accepted December 3, 2007

\begin{abstract}
Dendritic cells (DCs) play a pivotal role in T cellmediated immunity and have been shown to induce strong anti-tumor immune responses. As of yet, only a limited number of objective tumor regressions have been observed in clinical studies using a DC vaccine. Suppressor of cytokine signaling-1 (SOCS1) is a key negative regulator of the JAK/STAT signal pathway and plays an essential role in suppressing systemic autoimmunity that is mediated by DCs. The aim of this study was to investigate whether SOCS1-silenced DCs can break the vaccine-induced immune tolerance stimulated by highdose DC, thereby enhancing anti-tumor activity. In the mouse melanoma model, we found that a $2 \times 10^{6} \mathrm{TRP} 2$-pulsed $\mathrm{DC}$ vaccine was able to induce immune tolerance, while a $2 \times 10^{6}$ SOCS1-silenced DC/TRP2 vaccine prevented immune tolerance. Further experiments revealed that activation-induced $\mathrm{T}$ cell death (AICD) through the Fas/Fas-L pathway may play a crucial role in immune tolerance induced by $2 \times 10^{6}$ TRP2-pulsed DC. SOCS1-silencing in DCs could prevent immune tolerance by inhibiting Fas and Fas-L expression, induced by an increase in IL-12p70 and IL-6 production. In addition, in $2 \times 10^{6}$ SOCS1-silenced DC/TRP2 immunized mice, higher levels of IL-12p70 and IFN- $\gamma$ and lower IL-17 production may inhibit tumor angiogenesis and therefore assist in breaking immune tolerance. In conclusion, high-doses of DCs can inhibit the vaccine-induced AICD of T cells and cytokine regulation in tumor angiogenesis. These results indicate that SOCS1-silenced DC vaccines may greatly enhance anti-tumor activity by breaking self-tolerance.
\end{abstract}

Correspondence to: Dr Ying Qin Zang, Institute of Nutritional Sciences, Shanghai Institutes of Biological Sciences, Chinese Academy of Sciences, 294 Taiyuan Road, Shanghai 200031, P.R. China

E-mail: yqin@sibs.ac.cn

Key words: dendritic cell, immune tolerance, immunotherapy, SOCS1

\section{Introduction}

Dendritic cells (DCs) are professional antigen-presenting cells (APC) with key regulatory functions in the maintenance of tolerance to self-antigens and in the activation of innate and adaptive immunity (1). Suppressor of cytokine signaling-1 (SOCS1) serves to negatively regulate signaling of various cytokines, such as interferon (IFN)- $\gamma$, interleukin (IL)-2, IL-6, IL-7, IL-12 and IL-15, by inhibiting the Janus kinases (JAKs) in $\mathrm{T}$ cells and other immune cells $(2,3)$. The stimulatory capacity of DCs, as well as the magnitude of adaptive immunity, are critically regulated by SOCS1 (4). SOCS1 acts as an antigen-presentation attenuator by controlling the tolerogenic state of DCs and the magnitude of antigen presentation. Inhibition of SOCS1 significantly enhances the ability of DC-based tumor vaccines to break self-tolerance and to effectively induce anti-tumor immunity (4).

Although the results of various DC trials are exciting, the use of DCs in the clinic has achieved only limited success. The treated patients have not experienced tumor regression suggesting that the DC dose, route of administration and choice of antigen may need to be optimized (5). In addition, the results differ greatly due to the varied doses of DCs that have been used (6-9). In order to attain sufficient anti-tumor immunity, it may be necessary to use high doses of DCs in clinical trials (10).

Several mechanisms are involved in the induction of immune tolerance. Clonal anergy has been shown to be a major mechanism of certain immune tolerance states, such as oral tolerance and superantigen-induced tolerance (11-14). CD95(Fas)-dependent activation-induced cell death (AICD) appears to participate in maintaining peripheral tolerance by removing $\mathrm{T}$ cells specific for self-antigen, represented by high doses of systemic antigen in the absence of adjuvants (15-17). CD ${ }^{+} \mathrm{CD} 25^{+}$Treg cells have also been shown to play a major role in the maintenance of peripheral tolerance (18), and immune tolerance in vivo and in vitro can be induced by a signal from CTLA-4 (19,20). In addition, ICOS molecules play an essential and specific role in mucosal tolerance, and distinct co-stimulatory pathways differentially regulate peripheral tolerance. 
There is much evidence pointing towards the involvement of DCs in the induction of tolerance (21-25). The outcome of $\mathrm{T}$ cell stimulation by steady-state, antigen-loaded DCs can be apoptosis $(25,26)$, anergy of $\mathrm{T}$ cells in the periphery $(27)$ or the induction of regulatory $\mathrm{T}$ (Treg) cells $(25,28)$, depending on the state of DC maturation. Each of these mechanisms can result in some form of T cell tolerance (29); however, Tregs, CTLA-4 and ICOS were not related to immune tolerance in our study (data not shown).

In addition, angiogenesis, the formation of new blood vessels from the endothelium of the existing vasculature, is fundamental for tumor growth, progression and metastasis. Inhibiting tumor angiogenesis should slow tumor growth and is a promising strategy for cancer treatment (30). A large body of evidence indicates that cytokines, such as IFN- $\gamma$ and IL-12p70, could inhibit tumor angiogenesis, while IL-17 could promote it (31-35). Since SOCS1 functions as a negative regulator of signaling by various cytokines, silencing SOCS1 in bone marrow-derived DCs (BMDC) must change the production of some cytokines. The altered production of these cytokines could influence tumor growth and immune tolerance.

In this study, we found that SOCS-silencing could break the immune tolerance induced by $2 \times 10^{6}$ TRP2-pulsed DC vaccine. We then proceeded to investigate the mechanisms involved in this immune tolerance. We examined the role of activation-induced $\mathrm{T}$ cells apoptosis, and the secretion of certain cytokines (Th1, Th2 and IL-17) from spleen mononuclear cells (MNCs) of mice, which were immunized with different doses of DC/TRP2 or SOCS1-silenced DC/TRP2. Results showed that SOCS1-silencing in DCs could inhibit $\mathrm{T}$ cell apoptosis, enhance the secretion of IFN- $\gamma$, IL-12p70 and IL-6, and decrease IL-17 production. This study broadens the understanding of the function of SOCS1 protein and its usage in clinical trails.

\section{Materials and methods}

Cell lines and animals. B16 cell line (CRL-6475, ATCC, H-2 ${ }^{\mathrm{b}}$ ) was cultured in DMEM (Hyclone, Logan, UT) supplemented with $10 \%$ heat-inactivated FCS (Hyclone), 2 mM L-glutamine, $100 \mathrm{IU} / \mathrm{ml}$ penicillin and $100 \mathrm{mg} / \mathrm{ml}$ streptomycin.

Four to 6 week-old female C57BL/6 $\left(\mathrm{H}-2^{\mathrm{b}}\right)$ mice were purchased from SLAC Laboratory (Shanghai, P.R. China) and kept under controlled temperature $\left(22-23^{\circ} \mathrm{C}\right)$ and a $12-\mathrm{h}$ light/dark cycle with free access to water and pelleted food. Care and maintenance of all animals were in accordance with the Institutional Animal Care and Use Committee (IACUS) guidelines set by Shanghai Institutes for Biological Sciences.

Peptide and siRNA. The TRP2 peptide VYDFFVWL of B16 cell line was synthesized by GL Biochem (Shanghai) Ltd. and purified by HPLC.

Mouse SCOS1 siRNA (5'-CTA CCT GAG TTC CTT CCC CTT-3') and mouse SOCS1 siRNA mutant (5'-CTA TCT AAG TTA CTA CCC CTT-3'), described previously (4), were synthesized by Shanghai Genepharma Co. Ltd.

Generation of DC from bone marrow cultures. The protocols used in this study are as previously described $(4,22,36)$, with some minor modifications. Briefly, bone marrow cells from C57BL/6 mice were flushed from femurs and tibias. Red blood cells were removed by lysis with ammonium chloride. Bone marrow progenitors were seeded in a 24 -well plate $\left(1-2 \times 10^{6}\right.$ cells $/ \mathrm{ml}, 1 \mathrm{ml} /$ well) in RPMI-1640 (Hyclone) supplemented with $10 \%$ heat-inactivated FCS, $20 \mathrm{ng} / \mathrm{ml}$ recombinant murine GM-CSF (PeproTech, Inc.), $50 \mu \mathrm{M} 2-\mathrm{ME}$, $10 \mathrm{mM}$ HEPES, $2 \mathrm{mM}$ glutamine, $100 \mathrm{IU} / \mathrm{ml}$ penicillin and $100 \mathrm{mg} / \mathrm{ml}$ streptomycin. The cultures were fed every 2 days by gently aspirating $75 \%$ of the medium and adding fresh medium containing mGM-CSF. On day 6, non-adherent and loosely adherent proliferating DCs were collected and counted, then pulsed with TRP2 peptide $(50 \mu \mathrm{g} / \mathrm{ml})$ for $8 \mathrm{~h}$. Antigen-pulsed DCs were stimulated with $200 \mathrm{ng} / \mathrm{ml}$ LPS (Sigma-Aldrich) in 1640 CM10 for $24 \mathrm{~h}$. The collected DCs were washed twice with PBS, and resuspended in PBS for injection.

DC transfection with siRNA oligo. Bone marrow-derived DCs were transfected with 21 base-pair SOCS1 siRNA oligonucleotides or SOCS1 siRNA mutant using Geneporter, following the manufacturer's protocols. Briefly, $3 \mu \mathrm{l}$ of $20 \mu \mathrm{M}$ oligonucleotides was added to $3 \mu \mathrm{l}$ of geneporter reagent and $94 \mu \mathrm{l}$ of serum-free RPMI-1640 and incubated at room temperature for 30-45 min. Thereafter, $100 \mu 1$ of the Geneporter oligonucleotide mixture was added to each well of DC and incubated for $4 \mathrm{~h}$ at $37^{\circ} \mathrm{C}$. Following incubation, $500 \mu \mathrm{l} /$ well of RPMI-1640 supplemented with $20 \%$ FBS was added to bone marrow DCs.

DC immunization and tumor models. Different doses of TRP2 peptide pulsed DC, SOCS1-silenced DC (DC-S1) or DC-S1 mutant in $100 \mu 1 \mathrm{PBS}$ were injected into C57BL/6 mice twice weekly via footpad, followed by in vivo stimulation of LPS [30 $\mu \mathrm{g}$ in $200 \mu$ 1 PBS intraperitoneally (i.p.)] once daily for 3 days. One week following the second immunization, C57/BL6 mice were challenged subcutaneously (s.c.) in the left flank with B16 cells $\left(2.5 \times 10^{5} /\right.$ mouse $)$. Tumor volumes were measured 2-3 times a week with a caliper.

In the high-dose DC immunization experiment, C57BL/6J mice were immunized with $2 \times 10^{6}$ TRP2 pulsed DC, DC-S1 or DC-S1 mutant twice every two weeks. One week following the second immunization, mice from the above groups and the PBS control were s.c. inoculated with $2.5 \times 10^{5}$ B16 cells, respectively. Tumor volume was monitored every 2-3 days.

IFN- $\gamma$ enzyme-linked immunospot assay. IFN- $\gamma$ secretion, in response to specific antigens at the single-cell level, was detected by an enzyme-linked immunospot (ELISPOT) assay (BD Biosciences, San Diego, CA). Ninety 6-well PVDF microplates were coated overnight with an anti-murine IFN- $\gamma$ monoclonal antibody. The plates were washed 6 times with PBS and blocked with RPMI-1640 containing 10\% FBS at $37^{\circ} \mathrm{C}$ for $2 \mathrm{~h}$. Splenocytes $\left(5 \times 10^{5}\right)$ were seeded into wells and incubated with $20 \mu \mathrm{g} / \mathrm{ml}$ TRP2 peptide for $20 \mathrm{~h}$ at $37^{\circ} \mathrm{C}$ in $5 \% \mathrm{CO}_{2}$. Irrelevant peptide was also used as a negative control. The cells were then washed 6 times with PBS/0.5\% Tween-20. Biotinylated anti-mouse IFN- $\gamma$ antibody $(1 \mu \mathrm{g} / \mathrm{ml})$, diluted in PBS containing 0.5\% FBS was added and incubated at $25^{\circ} \mathrm{C}$ for $2 \mathrm{~h}$. Streptavidin-alkaline phosphatase was added 
and incubated at room temperature for an additional hour. Cytokine-secreting cells were detected after a 15-30-min reaction at room temperature in the dark with AEC (3-amino9-ethylcarbazole) and the reaction was terminated with distilled water washes. The membranes were air-dried and spots per well were subjected to automated evaluation using the ImmunoSpot Imaging Analyzer system (Cellular Technology Ltd., Cleveland, OH). IFN- $\gamma$ secreting cell numbers were calculated by averaging the number of spots from 3 replicate wells and expressed as the average number of spots per well $\pm \mathrm{SD}$.

Cytotoxicity assay by $\mathrm{LDH}$ release. The cytotoxic responses of $\mathrm{T}$ cells (mainly CD8 ${ }^{+} \mathrm{T}$ cells) from $1 \times 10^{6} \mathrm{DC}, 2 \times 10^{6} \mathrm{DC}$, $2 \times 10^{6} \mathrm{DC}-\mathrm{S} 1$ and $2 \times 10^{6} \mathrm{DC}-\mathrm{S} 1$ mutant immunized mice were assessed with LDH release assay (Cytotox $96^{\circledR}$ nonradioactive cytotoxicity assay, Promega Corp., Madison, WI, USA). The splenocytes, which were suspended in complete RPMI-1640 containing 10\% FCS and $50 \mu \mathrm{mol} / 1$ 2 -mercaptoethanol, were incubated with $20 \mu \mathrm{g} / \mathrm{ml}$ TRP2 peptide in vitro. Cytotoxic effector lymphocyte populations were harvested after 3 days of incubation. LDH-release assay was performed in a 96-well round bottom plate using B16 cells as the target cell. Cytotoxic T cells (CTL) assays were performed using lymphocyte effector:target (E:T) ratios of $20: 1,40: 1$, and $80: 1$. The percentage of specific lysis was calculated according to formula provided by the manufacturer.

Measurement of cytokine production. Spleen MNCs were prepared 7-11 days after the second DC immunization. Viable cells $\left(2 \times 10^{6}\right)$ were cultured in complete medium with TRP2 peptide at $20 \mu \mathrm{g} / \mathrm{ml}$. Supernatants from stimulated cells were collected at 24-72 $\mathrm{h}$ and the levels of IFN- $\gamma$, IL-4, IL-6, IL-10, IL-12p70, TGF- $\beta$ and IL-17 were measured by ELISA (R\&D Systems, Minneapolis, MN, USA) according to the manufacturer's instructions. A standard curve was performed for each plate and used to calculate the absolute concentrations of cytokines.

Quantitative real-time PCR. $\mathrm{CD}^{+}{ }^{+} \mathrm{T}$ cells were isolated with Dynabeads mouse CD4 (L3T4) kit (Dynal Biotech, Norway) according to the manufacturer's directions. Total-RNA was extracted from spleen MNCs or CD4 ${ }^{+} \mathrm{T}$ cells with RNeasy Mini kit (Qiagen, Hilden, Germany), followed by first-strand cDNA synthesis using Sensiscript RT kit (Qiagen), according to the manufacturer's instructions. Quantitative real-time RT-PCR was performed on a PRISM 7900 sequence detection system (Applied Biosystems, UK) with primer pairs using $\mathrm{SYBR}^{\circledR}$ green PCR master mix (Applied Biosystems). B-actin was used as a reference for sample normalization. Relative quantification of gene expression was calculated by using a $\Delta \mathrm{CT}$ method based on signal intensity of PCR results, according to the following formula: $\left.2^{-\Delta \mathrm{CT}}=\left[2^{- \text {(sample } \mathrm{Ct} \text { - normalizer } \mathrm{Ct}}\right)\right]$ $(\mathrm{Ct}=$ threshold cycle of real-time PCR). The primer sequences used were as follows: $\beta$-actin: sense primer, 5'-TGTCCACC TTCCAGCAGATGT-3'; antisense primer, 5'-AGCTCAGTA ACAGTCCGCCTAG-3'. mFas: sense primer, 5'-CTGCGAT GAAGAGCATGGTTT-3'; antisense primer, 5'-CCATAGG CGATTTCTGGGAC-3'. mFas-L: sense primer, 5'-AAGAA GGACCACAACACAAATCTG-3'; antisense primer, 5'-CCC
TGTTAAATGGGCCACACT-3'. mIL-23: sense primer, 5'TGTTGCCCTGGGTCACTCA-3'; antisense primer, 5'CCAGGCTAGCATGCAGAGATT-3'. mBcl-2: sense primer, 5'-ATGTCCAGTCAGCTGCACCTG-3'; antisense primer, 5'-CACAATCCTCCCCCAGTTCA-3'.

Flow cytometric and FACS analysis. In order to measure the expression of surface markers on DCs, cells $\left(0.5-1 \times 10^{6}\right)$ were incubated with either phycoerythrin (PE)-conjugated antimouse CD11c (N418, eBioscience), APC-conjugated antimouse CD80 (16-10A1, eBioscience), FITC-conjugated antimouse CD86 (GL1, eBioscience), CD40, FITC-conjugated anti-mouse $\mathrm{H}-2 \mathrm{k}^{\mathrm{b}}$ (AF6-88.5, BD), PE-conjugated anti-mouse I-A/I-E (M5/114.15.2, eBioscience) or their isotype control antibodies for $30 \mathrm{~min}$ at $4^{\circ} \mathrm{C}$. Stained cells were fixed with $2 \%$ paraformaldehyde and analyzed by a FACSCalibur (BD Biosciences).

The annexin V/propidium iodide (PI) assay was used to measure the amount of apoptosis of T cells, whereby spleen MNCs from DC or DC-S1 immunized mice $(n=4)$ were stimulated with $20 \mu \mathrm{g} / \mathrm{ml}$ TRP2 peptide for $24 \mathrm{~h}$. Cells $\left(1 \times 10^{5}\right)$ were incubated with Annexin V-FITC and PI (BD Pharmingen, San Diego, CA) at room temperature for $15 \mathrm{~min}$ according to the manufacturer's instructions. Within one hour, stained cells were analyzed by FACS.

For the detection of Fas expression on $\mathrm{CD}^{+}$and $\mathrm{CD}^{+} \mathrm{T}$ cells of stimulated spleen MNCs, cells were incubated with FITC-conjugated anti-mouse CD4/CD8 antibodies and PE-conjugated anti-mouse Fas/CD95 (eBiosciences) or their isotype control antibodies for $30 \mathrm{~min}$ at $4{ }^{\circ} \mathrm{C}$, followed by washing and fixation with $2 \%$ paraformaldehyde. Cells were then stored at $4^{\circ} \mathrm{C}$ for further FACS analysis.

Statistical analyses. All statistical analyses in this study were performed with the Student's t-test, and a probability of $<95 \%$ confidence limit was considered to be significant, defined as $\mathrm{p}<0.05$. Results are presented as means \pm standard deviation (SD).

\section{Results}

Maturation status of BM-DC/TRP2 and SOCS1-silenced $B M-D C / T R P 2$. To determine the maturation status of BMDC/TRP2 and SOCS1-silenced BM-DC/TRP2, FACS analysis was performed on cell suspensions from day 7. DCs were prepared from bone marrow precursors and harvested for use 7 days after culture in 1640 CM10 media containing mGM-CSF. After SOCS1 silencing, TRP2 peptide loading, and LPS stimulation in vitro, DCs were stained by flow cytometry to analyze surface expression of CD11c, MHC I/II molecules, co-stimulatory molecules and antigens associated with maturation. The data showed that DCs expressed high levels of the above-mentioned surface molecules, and mature SOCS1-silenced BM-DC/TRP2 express more DC markers, co-stimulatory molecules, MHC class I and class II molecules than mature DC/TRP2 (Fig. 1A). The production of IL-4, IL-6, IL-10, IL-12p70 and TNF- $\alpha$ by SOCS1-silenced BMDC/TRP2 and DC/TRP2 in culture supernatant was measured after stimulation with $200 \mathrm{ng} / \mathrm{ml}$ of LPS for $24 \mathrm{~h}$. Both SOCS1-silenced BM-DC/TRP2 and DC/TRP2 secreted high 
A.

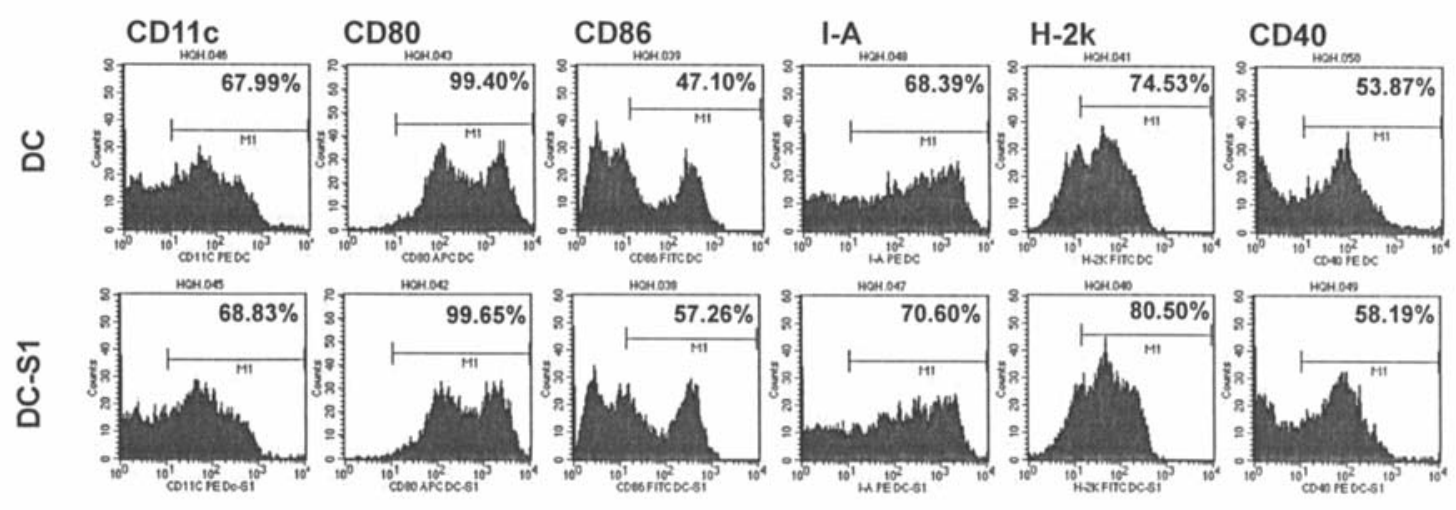

B.

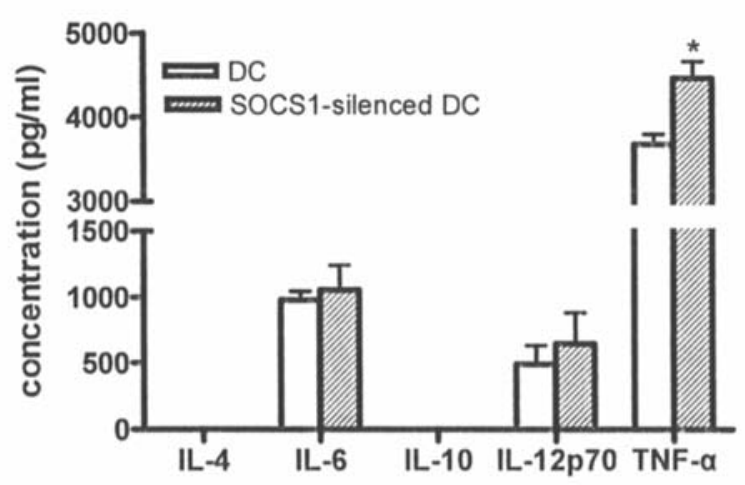

Figure 1. Maturation status of bone-marrow derived dendritic cells (BM-DC). (A) FACS surface profiles of BM-DC or SOCS1-silenced BM-DC (DC-S1) analyzed at day 8. Mature SOCS1-silenced BM-DC/TRP2 express more DC markers (CD11c), co-stimulatory molecules (CD86, CD40), MHC class I (H-2k) and MHC class II (I-A) molecules than mature DC/TRP2. (B) Cytokine profiles of mature dendritic cells. DC culture supernatant was collected after addition of $200 \mathrm{ng} / \mathrm{ml}$ LPS to the DC culture for $24 \mathrm{~h}$. The levels of IL-4, IL-10, IL-12p70, TNF- $\alpha$ and IFN- $\gamma$ from SOCS1-silenced BM-DC/TRP2 (DC-S1) and DC/TRP2 were measured by ELISA. Asterisks indicate statistically significant differences between two groups $\left({ }^{*} \mathrm{p}<0.05\right)$.

levels of IL-6, IL-12p70 and TNF- $\alpha$, but the levels of the three cytokines produced by DC-S1 were higher than DC (Fig. 1B).

Silencing SOCS1 can break tolerance induced by highdosage DC inoculation. To evaluate the anti-tumor immunity of different doses of DC, C57BL/6J mice $(n=10)$ were inoculated with $5 \times 10^{5}, 1 \times 10^{6}, 2 \times 10^{6}$ TRP2-pulsed BMDC. PBS was used as a control. One week after the second immunization, the mice were challenged with B16 cells. As shown in Fig. 2a, there was a significant difference in antitumor immunity among the TRP2-pulsed DC groups $(\mathrm{p}<0.05)$. Anti-tumor immunity was induced effectively with $5 \times 10^{5}$ and $1 \times 10^{6}$ TRP2-pulsed DCs, while $2 \times 10^{6}$ TRP2pulsed DCs induced immune tolerance.

To determine the role of SOCS1-silencing in immune tolerance, anti-tumor immunity of $2 \times 10^{6}$ DC/TRP2, DC-S1/ TRP2 and DC-S1 mutant/TRP2 were compared in the mouse B16 model. One week after the second immunization, mice from the immunized groups and PBS control group were inoculated subcutaneously with $2.5 \times 10^{5} \mathrm{~B} 16$ cells. The tumor volume was monitored every 2-3 days. As shown in Fig. 2b, the tumor volume of mice inoculated with $2 \times 10^{6}$ DC-S1/TRP2 displayed a significant difference $(\mathrm{p}<0.01)$ versus $2 \times 10^{6}$
DC-S1 mutant /TRP2 and PBS control groups, as well as the $2 \times 10^{6} \mathrm{DC} / \mathrm{TRP} 2$ group $(\mathrm{p}<0.05)$. The results suggest that SOCS1-silencing could terminate the immune tolerance induced by $2 \times 10^{6}$ DC/TRP2. Furthermore, as shown in Fig. 2c, the tumor volume of mice immunized with different doses of DC-S1 was significantly decreased $\left(\mathrm{p}<0.05\right.$ for $5 \times 10^{5}$ and $1 \times 10^{6} ; \mathrm{p}<0.01$ for $2 \times 10^{6}$ ) versus different dose DC or DC-S1 mutant immunized groups.

In survival studies (Fig. 2d), C57BL/6 mice $(n=7)$ were immunized with $2 \times 10^{6}$ DC-S1, DC-S1 mutant, DC and PBS control twice, and subsequently challenged with B16 tumor cells as above. All mice challenged with PBS and $2 \times 10^{6}$ DC died within 32 days post-B16 cell challenge. Two mice in the $2 \times 10^{6}$ DC-S1 group displayed no visible tumor growth and survived past 10 weeks. The survival rate of the $2 \times 10^{6} \mathrm{DC}-\mathrm{S} 1$ group was significantly higher $(\mathrm{p}<0.05)$ than the $2 \times 10^{6} \mathrm{DC}$ or DC-S1 mutant and PBS control groups $(\mathrm{p}<0.05)$.

Antigen specific $T$ cell responses ex vivo. SOCS1 contributes to the regulation of DC stimulation of antigen-specific $\mathrm{T}$ cells (4). To measure the antigen-specific cellular response induced by $2 \times 10^{6}$ SOCS 1 -silenced DCs, IFN- $\gamma$ secreting frequency assay by ELISPOT and CTL activities by LDH assay were performed. As shown in Fig. $3 \mathrm{a}$, IFN- $\gamma$ secreting 


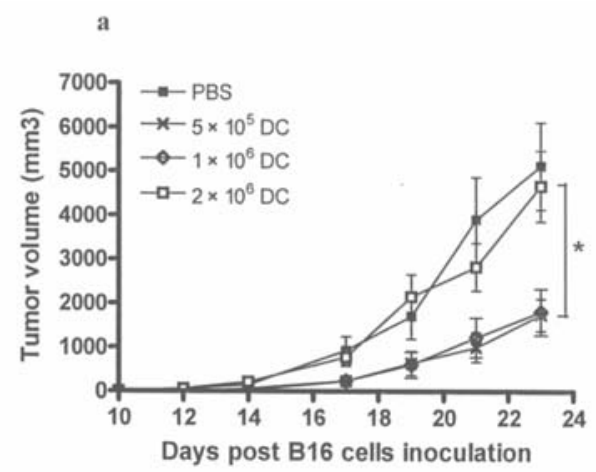

c

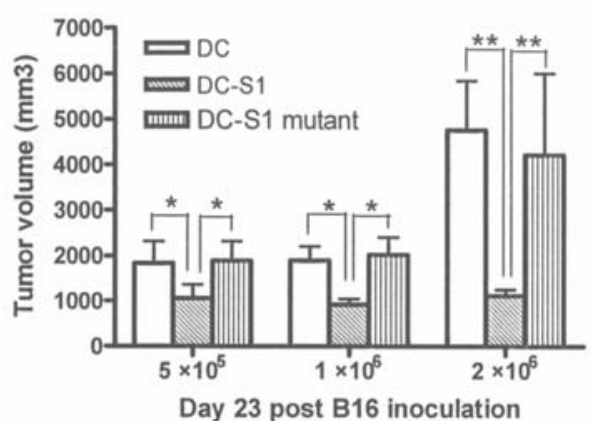

b

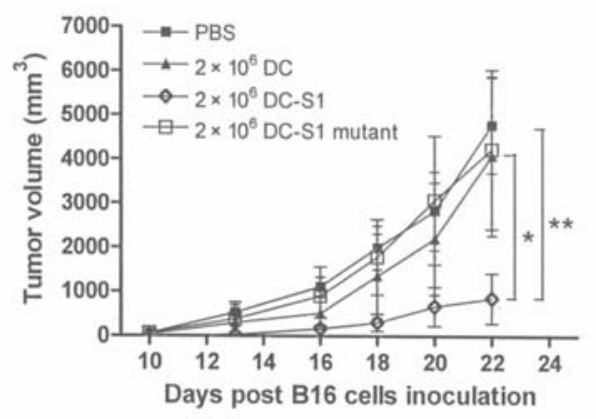

d

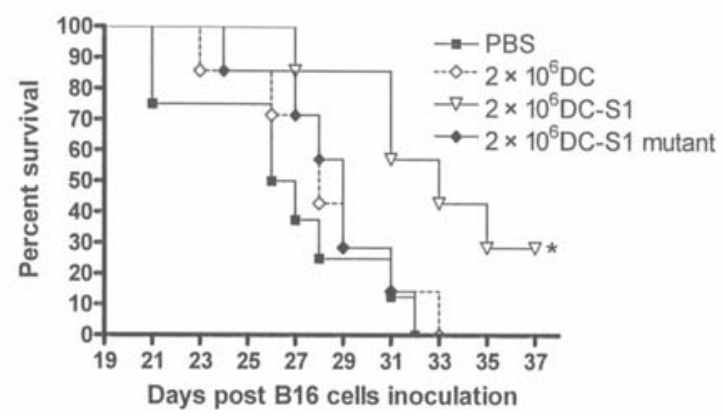

Figure 2. SOCS1-silenced DC could break the tolerance induced by high-dosage DC inoculation. (a) DC/TRP2 immunization $\left(2 \times 10^{6}\right)$ could induce immune tolerance in the B16 model. C57BL/6J mice were inoculated twice with $2 \times 10^{6}, 1 \times 10^{6}, 5 \times 10^{5} \mathrm{DC} / \mathrm{TRP} 2$ and PBS respectively (n=10). One week after the second immunization, mice were challenged with $2.5 \times 10^{5}$ B16 cells subcutaneously. Tumor volumes were measured every 2-3 days. (b) SOCS1-silencing was able to break immune tolerance induced by $2 \times 10^{6} \mathrm{DC} / \mathrm{TRP} 2$. The results are expressed as mean (tumor volume) $\pm \mathrm{SD}$. Tumor growth curves represent one of three independent experiments. (c) Tumor volume of mice immunized with different doses of DC, DC-S1 and DC-S1 mutant respectively at 23 days post B16 cells inoculation. (d) The survival ratio of $2 \times 10^{6} \mathrm{DC}$, DC-S1 and DC-S1 mutant immunized mice. Asterisks indicate statistically significant differences between two groups $\left({ }^{*} \mathrm{p}<0.05,{ }^{* *} \mathrm{p}<0.01\right)$.

a

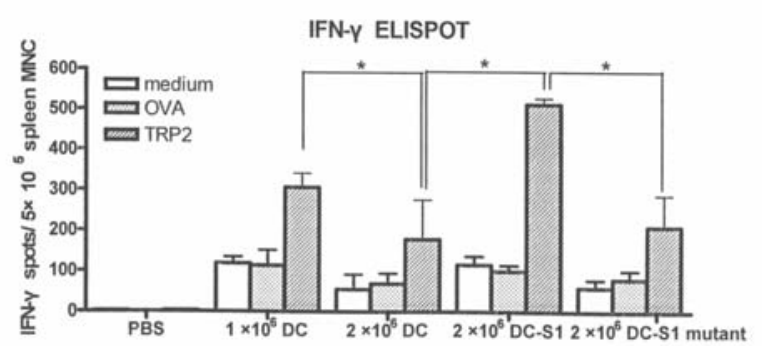

b

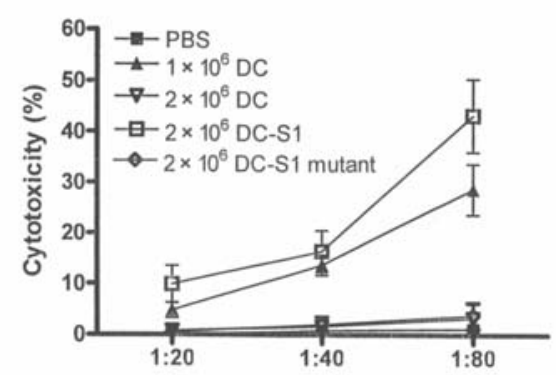

Figure 3. Antigen-specific T cell response induced by $2 \times 10^{6}$ SOCS1-silenced DCs. (a) Spleen MNCs from mice $(n=4)$ which were inoculated with $1 \times 10^{6}$ DC, $2 \times 10^{6}$ DC, $2 \times 10^{6}$ DC-S1 and $2 \times 10^{6}$ DC-S1 mutant were cultured with $20 \mu \mathrm{g} / \mathrm{ml}$ TRP2, OVA peptide or medium only for $20 \mathrm{~h}$. IFN- $\gamma$ secreting frequency assay by ELISPOT was analyzed. (b) Spleen MNCs from immunized mice $(\mathrm{n}=4)$ were cultured with $20 \mu \mathrm{g} / \mathrm{ml}$ TRP2 peptide for $68-72 \mathrm{~h}$. The cytotoxic responses were performed by LDH-release assay in a 96-well round bottom plate using B16 cells as target cells. Asterisks indicate statistically significant differences between two groups $\left({ }^{*} \mathrm{p}<0.05,{ }^{* *} \mathrm{p}<0.01\right)$. spots $(514 \pm 16$ and $189 \pm 98)$ were detected ex vivo by ELISPOT in $5 \times 10^{5}$ spleen MNCs of mice $(n=4)$ that had been immunized two times with $2 \times 10^{6}$ SOCS1-silenced DC/TRP2 and $2 \times 10^{6}$ DC/TRP2, respectively; there was a significant difference between the two groups $(\mathrm{p}<0.05)$. Cytotoxicity of antigenspecific $\mathrm{T}$ cells (CTLs, mainly $\mathrm{CD} 8^{+} \mathrm{T}$ cells) is an important marker of anti-tumor immunity. For this reason, we compared the CTLs in vitro from $1 \times 10^{6} \mathrm{DC}, 2 \times 10^{6} \mathrm{DC}, 2 \times 10^{6} \mathrm{DC}-\mathrm{S} 1$ and $2 \times 10^{6}$ DC-S 1 mutant immunized mice. As shown in Fig. 3b, CTL assays showed potent cytotoxicity against B16 cells in $2 \times 10^{6}$ SOCS1-silenced DC/TRP2 immunized mice, but not in the $2 \times 10^{6} \mathrm{DC} / \mathrm{TRP} 2$ or $2 \times 10^{6} \mathrm{DC}-\mathrm{S} 1$ mutant group. Active cytotoxicity against B16 cells in $2 \times 10^{6}$ DC-S1 immunized mice was significantly different from that detected in $2 \times 10^{6}$ DC immunized mice $(\mathrm{p}<0.05)$. In addition, $1 \times 10^{6} \mathrm{DC}$ was also significantly different from $2 \times 10^{6} \mathrm{DC}$ immunized mice $(\mathrm{p}<0.05)$.

$T$ cell apoptosis plays a crucial role in immune tolerance induced by $2 \times 10^{6} \mathrm{DC}$ inoculation. To examine whether immune tolerance induced by $2 \times 10^{6} \mathrm{DC}$ inoculation was related to activation-induced $\mathrm{T}$ cell death (AICD), apotosis measurements were performed with annexin V/PI staining. Annexin $\mathrm{V}$ identifies cells in the early stages of apoptosis. Cells in the late stages of apoptosis will have a damaged membrane and, therefore, stain positive for PI, as well as for annexin $\mathrm{V}$. The spleen MNCs from $2 \times 10^{6}, 1 \times 10^{6}$ and $5 \times 10^{5}$ SOCS1-silenced DC/TRP2 or DC/TRP2 were cultured with TRP2 peptide for $24 \mathrm{~h}$, then the cells were collected for 
a
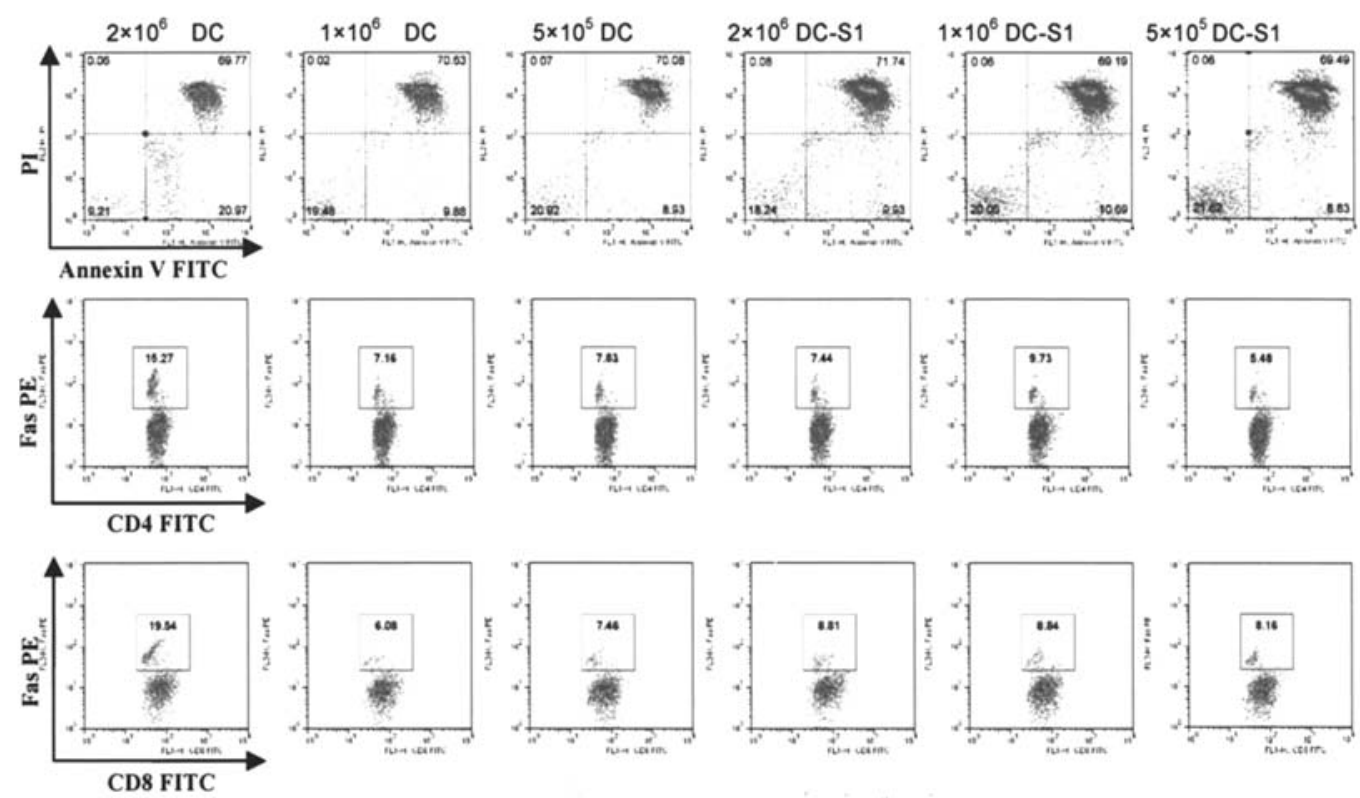

b

c.

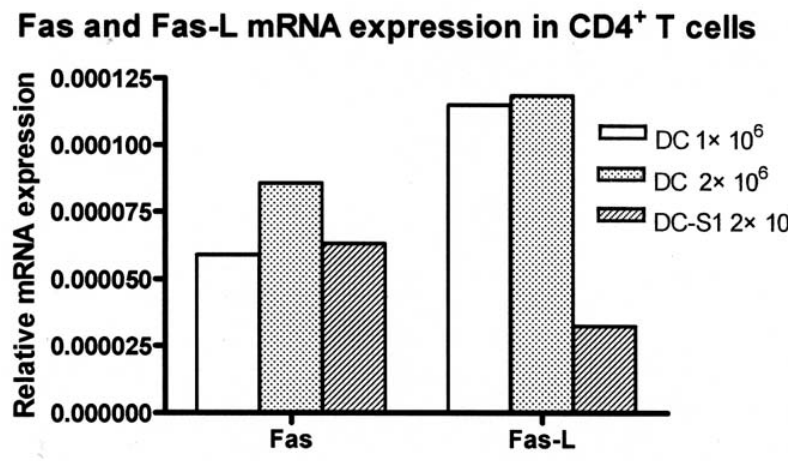

Bcl-2 mRNA expression in $\mathrm{CD}^{+} \mathrm{T}$ cells

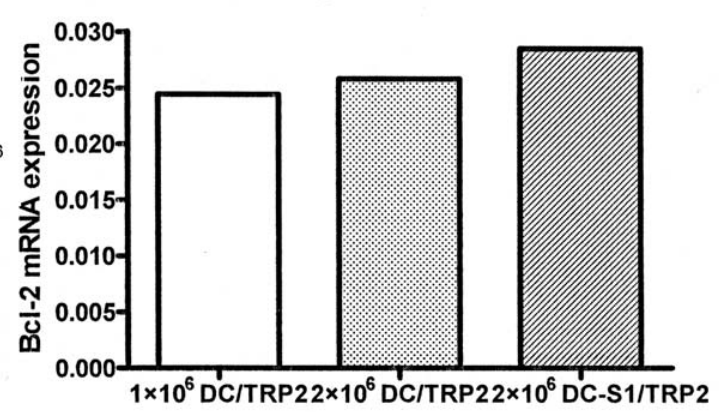

Figure 4. Apoptosis plays a crucial role in the immune tolerance induced by $2 \times 10^{6} \mathrm{DC}$ inoculation in B16 model. (a) Apoptosis and Fas expression detection by FACS. Spleen MNCs from mice $(\mathrm{n}=4)$ which were immunized twice with $2 \times 10^{6}, 1 \times 10^{6}$ and $5 \times 10^{5}$ DC/TRP2 or SOCS1-silenced DC/TRP2 were cultured with $20 \mu \mathrm{g} / \mathrm{ml} \mathrm{TRP} 2$ peptide for $24 \mathrm{~h}$. Apoptosis was detected by annexin V/PI assay. Fas expression on CD4 ${ }^{+} / \mathrm{CD} 8^{+} \mathrm{T}$ cells was analyzed by flow cytometry. (b and c) Real-time PCR for Fas, Fas-L and Bcl-2 for mRNA expression in $\mathrm{CD}^{+} \mathrm{T}$ cells of immunized mice.

annexin V-FITC/PI staining (BD Pharmingen). As shown in Fig. 4a, annexin V-FITC positive cells were almost 2-fold $(21.08 \%)$ greater in the $2 \times 10^{6} \mathrm{DC} / \mathrm{TRP} 2$ group than in the other groups $(8.31-11.78 \%)$.

To investigate, in the $2 \times 10^{6} \mathrm{DC} / \mathrm{TRP} 2$ group, the role of Fas/FasL signaling in $\mathrm{T}$ cell apoptosis, we examined Fas (CD95) expression on $\mathrm{CD}^{+} \mathrm{T}$ cells by flow cytometry. Higher levels of CD95 (Fas) expression on CD3 ${ }^{+} \mathrm{T}$ cells were observed (data not shown). In the Fas/Fas-L pathway, Fas-L induces Fas-positive cells to undergo apoptosis. Therefore, cells that express Fas molecules become target cells for apoptosis. Both $\mathrm{CD}^{+}$and $\mathrm{CD} 8^{+} \mathrm{T}$ cells are important factors for tumor immunity. Tumor-specific $\mathrm{CD}^{+}$ $\mathrm{T}$ cell responses are often crucial for tumor eradication. However, CD4 ${ }^{+} \mathrm{T}$ lymphocytes are a key element in the optimal activation of $\mathrm{CD}^{+} \mathrm{T}$ cells, and also facilitate tumor immunity and maintenance of immune memory. To further determine whether $\mathrm{CD}^{+}{ }^{+}$and/or $\mathrm{CD} 8^{+} \mathrm{T}$ cells undergo apoptosis, Fas expression of $\mathrm{CD}^{+}$and $\mathrm{CD} 8^{+} \mathrm{T}$ cells was analyzed by flow cytometry. As shown in Fig. 4a, the expression levels of Fas on $\mathrm{CD}^{+}$and $\mathrm{CD} 8^{+} \mathrm{T}$ cells from the $2 \times 10^{6}$ DC/TRP2 group was significantly higher than other groups. In line with the results in Fig. $4 \mathrm{a}$, the result of quantitative real-time RT-PCR of Fas/Fas-L mRNA also revealed that the mRNA expression of Fas in $\mathrm{CD}^{+}{ }^{+} \mathrm{T}$ cells in vivo from $2 \times 10^{6} \mathrm{DC} / \mathrm{TRP} 2$ immunized mice was higher than $2 \times 10^{6}$ DC-S1/TRP2 and $1 \times 10^{6}$ DC/TRP2 immunized mice. Conversely, the relative Fas-L mRNA expression of $\mathrm{CD}^{+}{ }^{+} \mathrm{T}$ cells from $1 \times 10^{6}$ and $2 \times 10^{6} \mathrm{DC}-\mathrm{S} 1 / \mathrm{TRP} 2$ immunized mice was almost 5 -fold higher than that of $2 \times 10^{6} \mathrm{DC}-\mathrm{S} 1 / \mathrm{T}$ RP2 immunized mice (Fig. 4b). Both Fas and Fas-L molecules were highly expressed on $\mathrm{CD}^{+} \mathrm{T}$ cells from $2 \times 10^{6} \mathrm{DC}$ $\mathrm{S} 1 / \mathrm{TRP} 2$ immunized mice, which indicates that the expression of Fas- $\mathrm{L}$ in $\mathrm{CD}^{+} \mathrm{T}$ cells could be sufficient to induce apoptosis. Lower Fas and Fas-L expression in $\mathrm{T}$ cells may explain why apoptosis induction was lower in $2 \times 10^{6}$ DC- 

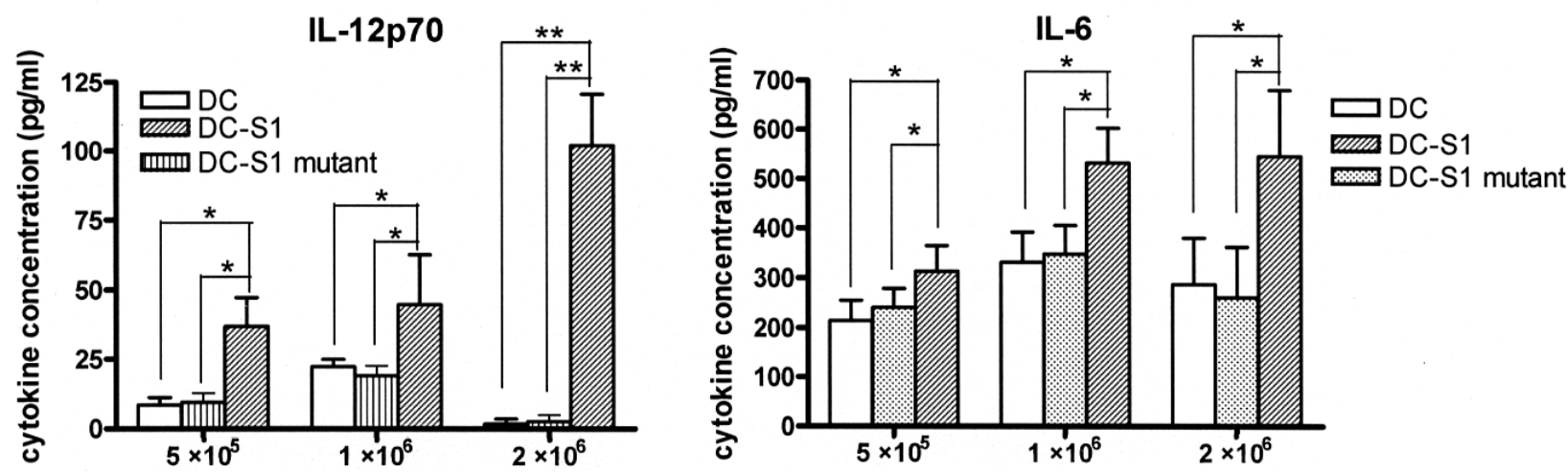

Figure 5. The production of IL-12p70 and IL-6, which could inhibit Fas and/or Fas-L expression, was measured by ELISA. C57BL/6 mice were immunized twice with different doses of TRP2-pulsed DC, DC-S1 and DC-S1 mutant respectively. Two weeks after second DC inoculation, the spleen MNCs from mice of three groups ( $\mathrm{n}=4$ ) were cultured with $20 \mu \mathrm{g} / \mathrm{ml}$ TRP2 peptide for $72 \mathrm{~h}$. The levels of IL-12p70 (a) and IL-6 (b) in culture supernatant were measured by ELISA. Asterisks indicate statistically significant differences between two groups $\left({ }^{*} \mathrm{p}<0.05,{ }^{* *} \mathrm{p}<0.01\right)$

S1/TRP2 immunized mice than that in $2 \times 10^{6}$ DC/TRP2immunized mice. In addition, Bcl-2 mRNA expression was not significantly different among $1 \times 10^{6}$ DC/TRP2, $2 \times 10^{6}$ DC/TRP2 and $2 \times 10^{6}$ DC-S1/TRP2 groups (Fig. 4c).

IL-12p70 and IL-6 production in DC-immunized mice. Since SOCS1 negatively regulates the signaling of various cytokines, breaking the immune tolerance by SOCS1-silenced dendritic cells must be related to altered production of certain cytokines. To determine the mechanism by which $2 \times 10^{6}$ SOCS1-silenced DC/TRP2 can break immune tolerance, cytokine profiles of cultured spleen MNC supernatants of immunized mice were analyzed by ELISA. IL-12 has been shown to inhibit apoptosis of $\mathrm{CD}^{+}$and $\mathrm{CD} 8^{+} \mathrm{T}$ cells by decreasing Fas-L expression and promoting FLIP expression $(37,38)$. As shown in Fig. 5a, the level of IL-12p70 was measured by ELISA. The results showed that IL-12p70 production in the $2 \times 10^{6} \mathrm{DC}-\mathrm{S} 1 / \mathrm{TRP} 2$ group was significantly higher than that of the $2 \times 10^{6} \mathrm{DC} / \mathrm{TRP} 2$ and $2 \times 10^{6} \mathrm{DC}-\mathrm{S} 1$ mutant/TRP2 groups $(\mathrm{p}<0.01)$. In the other two SOCS1-silenced DC groups, IL-12p70 production was also higher than the corresponding DC dose group $(\mathrm{p}<0.05)$. We suggest that IL-12 might act as an inhibitor of immune tolerance induced by high-dose DC. Lower Fas-L mRNA expression in $\mathrm{CD}^{+} \mathrm{T}$ cells from $2 \times 10^{6}$ DC-S1/TRP2 immunized mice (Fig. 4b) indicates an indirect role for IL-12.

IL-6 also prevented activation-induced T cell death by inhibiting Fas/Fas-L expression (39). As shown in Fig. 5b, the level of IL- 6 in the $2 \times 10^{6}$ DC-S1/TRP2 group was significantly higher than that of the $2 \times 10^{6} \mathrm{DC} / \mathrm{TRP} 2$ and $2 \times 10^{6} \mathrm{DC}-\mathrm{S} 1$ mutant/TRP2 groups $(\mathrm{p}<0.05)$.

Tumor angiogenesis-related cytokines production. Immune tolerance observed in our study was based mainly on tumor volume changes. This underscores the importance of understanding and studying the factors that influence tumor growth. Some studies have already indicated that tumor growth is an angiogenesis-dependent process that requires sustained new vessel growth (31), and IFN- $\gamma$ and IL-17 have been confirmed to inhibit/promote tumor angiogenesis, respectively. To evaluate the effect of SOCS1-silencing on tumor angiogenesis-related cytokine production in our studies, the secretion levels of IFN- $\gamma$ and IL-17 were measured.

As shown in Fig. $6 \mathrm{a}$, IFN- $\gamma$ production in the $5 \times 10^{5}, 1 \times 10^{6}$ and $2 \times 10^{6}$ DC-S1 groups was significantly higher than that of the corresponding doses in DC groups $(\mathrm{p}<0.05)$; however, there was no significant difference among the DC-S1 groups $(\mathrm{p}>0.05)$. IFN- $\gamma$ production in $2 \times 10^{6} \mathrm{DC}$ immunized mice showed a large standard deviation (SD) (Fig. 6a), suggesting that IFN- $\gamma$ secreting $\mathrm{T}$ cells may be at different apoptotic stages (activation-induced cell death was detected in this study).

Substantial evidence suggests that IL-17 could promote angiogenesis and tumor growth $(31,40)$. To determine whether IL-17 cytokine production was different between the high-dose DC/TRP2 group and the DC-S1/TRP2 group in the B16 model, levels of IL-17 from cultured supernatants were measured by ELISA. Significantly lower levels of IL-17 production were measured by ELISA in the $2 \times 10^{6}$ DC-S1immunized mice compared to the $1 \times 10^{6} \mathrm{DC}$ and $2 \times 10^{6} \mathrm{DC}-$ immunized mice ( $<<0.05$, Fig. $6 b$ ).

IL-23 serves to expand previously differentiated $\mathrm{TH}-17$ cell populations, whereas IL- 6 and transforming growth factor- $\beta$ (TGF- $\beta$ ) induced differentiation of TH-17 cells from naive precursors (41). However, levels of IL-6 (Fig. 5b, $\mathrm{p}<0.05$ ) and TGF- 3 (data not shown) in $2 \times 10^{6} \mathrm{DC}$ immunized mice were significantly lower than those in $2 \times 10^{6} \mathrm{DC}-\mathrm{S} 1$ immunized mice, so we measured IL-23 mRNA expression by quantitative real-time PCR. As shown in Fig. 6c, IL-23 mRNA expression in different doses of SOCS1-silenced $\mathrm{DC} / \mathrm{TRp} 2$ groups is lower than that of corresponding doses of DC/TRP2 groups, suggesting that decreased IL-23 expression may contribute to lower IL-17 production in $2 \times 10^{6}$ DC-S1immunized mice.

\section{Discussion}

The determination of a lymphocyte to affect either tolerance or immunity is regulated at many levels. Two important parameters in this decision are the maturation state of the 
a

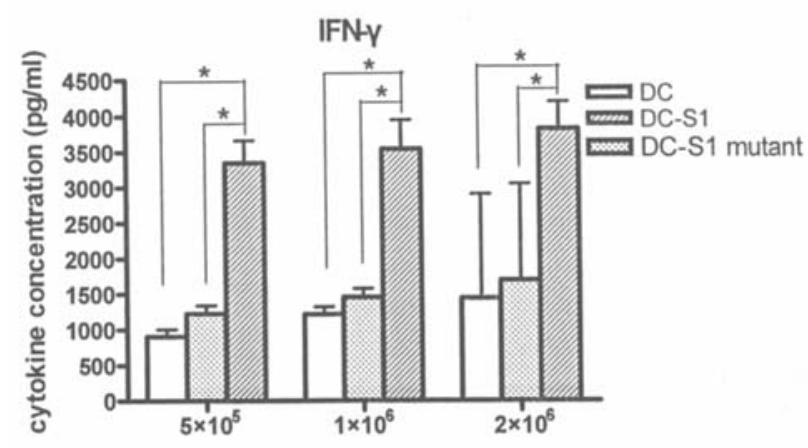

c b

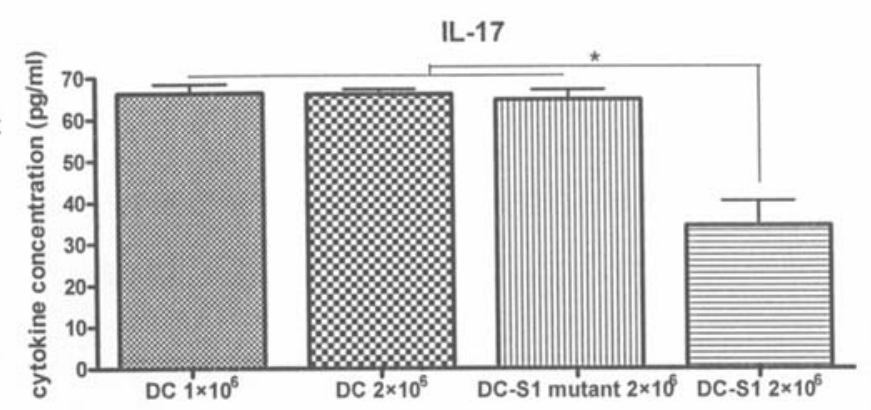

IL-23 mRNA

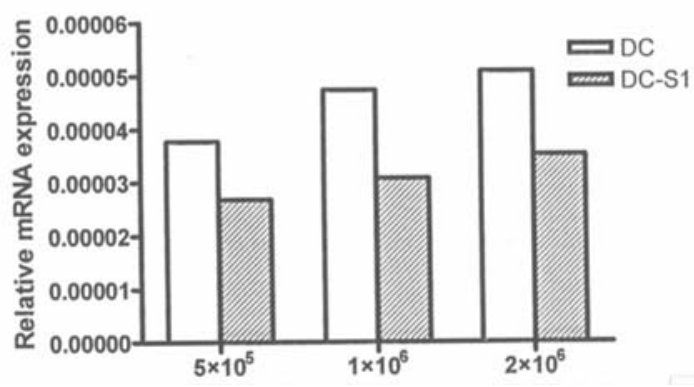

Figure 6. The production of IFN- $\gamma$ and IL-17, influencing angiogenesis, was measured by ELISA. C57BL/6 mice were immunized twice with different doses of TRP2-pulsed DC, DC-S1 and DC-S1 mutant respectively. Two weeks after second DC inoculation, the spleen MNCs from mice of three groups ( $\mathrm{n}=4$ ) were cultured with $20 \mu \mathrm{g} / \mathrm{ml}$ TRP2 peptide for $72 \mathrm{~h}$. The levels of IFN- $\gamma$ (a) and IL-17 (b) in culture supernatants were measured by ELISA. (c) IL-23 mRNA expression in spleen MNCs was measured by real-time PCR. Spleen MNCs were cultured in vitro with $20 \mu \mathrm{g} / \mathrm{ml}$ TRP2 peptide for $24 \mathrm{~h}$. Quantitative real-time PCR was performed using SYBR green on an ABI PRISM 7900 sequence detection system. Asterisks indicate statistically significant differences between a given group and the other groups $\left({ }^{*} \mathrm{p}<0.05\right)$.
APCs and the amount of antigen detected by the immune system (42). The maturation state of DCs is considered to be a key determinant for the outcome of $\mathrm{T}$ cell activation $(1,22)$. For example, immature DCs can anergize autoreative T cells in the periphery or lead to the induction of regulatory $\mathrm{T}$ cells (24). Semi-mature DCs have also been shown to induce tolerance (29). Lutz and Schuler termed the tolerogenic DCs (MHC II $^{\text {high }}$, costimulation ${ }^{\text {high }}$, cytokines ${ }^{\text {low }}$ ) as 'semi-mature', and the immunogenic DCs (MHC $\mathrm{II}^{\text {high }}$, costimulation ${ }^{\text {high }}$, cytokines $^{\text {high }}$ ) as 'fully mature' (22). In our study, prepared bone marrow-derived DC/TRP2 or SOCS1-silenced DC/TRP2 expressed high levels of MHC and co-stimulatory molecules and secreted high levels of IL-12, TNF- $\alpha$ and IL-6. Moreover, these DCs induced effective anti-tumor immunity in immunized C57BL/6J mice. As a result, we concluded that prepared DCs were fully mature.

SOCS1 plays a crucial role in regulating the extent of DC antigen presentation, and the modulation of a DC regulatory mechanism has been an effective way to control the magnitude and duration of adaptive immunity $(4,43)$. In our study, SOCS1-silenced DCs displayed higher levels of CD11c, MHC and co-stimulatory molecules. We therefore conclude that immunization in mice can lead to changes in cytokine production, the extent of $\mathrm{T}$ cell activation and the modulation of these mechanisms.

Activation-induced cell death (AICD) is a process in which $\mathrm{T}$ cell activation, by way of the $\mathrm{T}$ cell receptor, results in apoptosis (44). AICD plays a key role in tolerance induction and lymphocyte homeostasis. The results of annexin V/PI staining showed that the proportion of cells at early stages of apoptosis in the $2 \times 10^{6}$ TRP2-pulsed DC group was 2-fold greater in contrast to other groups, which suggests that apoptosis is an important factor for immune tolerance. The Fas/Fas ligand pathway is the predominant mechanism for AICD in peripheral $\mathrm{T}$ cells (44). Flow cytometry analysis showed Fas expression was higher in both $\mathrm{CD}^{+}$and $\mathrm{CD}^{+} \mathrm{T}$ cells from the $2 \times 10^{6}$ TRP2-pulsed DC group than the other groups. It was suggested that both $\mathrm{CD}^{+}$and $\mathrm{CD} 8^{+} \mathrm{T}$ cells underwent apoptosis. It has been shown that in order to aquire an optimal anti-tumor immune response, the concomitant activation of both the $\mathrm{CD}^{+}$and $\mathrm{CD}^{+} \mathrm{T}$ cell arm of the immune response is required (45). A potent $\mathrm{CD} 8^{+} \mathrm{CTL}$ response is the key to protective immune responses against tumors. Accumulating evidence strongly suggests that the $\mathrm{CD}^{+} \mathrm{T}$ cell arm of the immune response also plays a critical role in mediating anti-tumor immunity $(46,47)$. This suggests that apoptosis of $\mathrm{CD}^{+}$and $\mathrm{CD} 8^{+} \mathrm{T}$ cells should lead to immune tolerance.

Why are $2 \times 10^{6}$ SOCS1-silenced DC/TRP2 inoculated cells resistant to apoptosis? According to our data, Fas expression of $\mathrm{CD}^{+}$and $\mathrm{CD}^{+} \mathrm{T}$ cells in the $2 \times 10^{6} \mathrm{SOCS} 1$-silenced DC/TRP2 group was similar to lower dose DC groups. Since IFN- $\gamma$ has been previously shown to up-regulate Fas expression in vitro and in vivo $(48,49)$, we proceeded to measure IFN- $\gamma$ production. Our results showed that the production of IFN- $\gamma$ was significantly higher in the various doses of DC-S1/TRP2immunized mice than DC/TRP2 and DC-S1 mutant/TRP2immunized mice. Nevertheless, Fas expression was up-regulated nearly 2 -fold in the $2 \times 10^{6} \mathrm{DC}$ - immunized group when compared to the other groups. It is assumed that certain factors, which existed in the $2 \times 10^{6}$ SOCS1-silenced DC-immunized mice, inhibited $\mathrm{T}$ cell apoptosis by decreasing Fas expression. 
Substantial evidence has led to the belief that IL-12 and IL-6 can inhibit Fas and/or Fas-L expression in T cells in AICD. IL-12 has been shown to inhibit apoptosis of $\mathrm{CD}^{+}$and $\mathrm{CD}^{+} \mathrm{T}$ cells and can prevent activation-induced or Fasmediated apoptosis of human CD4 T cells (37). In the mouse, neutralization of endogenous IL-12 promoted Fas-mediated apoptosis of CD4 T cells in vivo (50) and co-stimulation with IL-12 significantly prevented anti-CD3-induced apoptosis of CD8 T cells (38). It was also shown that IL-12 decreased the number of Fas ligand-positive CD8 T cells and inhibited the activation of caspase- 8 and -3 . In addition, IL-12 upregulated cellular FLIPs, but not Bcl-2 family proteins or the cellular inhibitors of apoptosis proteins (38). In our study, the level of IL-12 in the $2 \times 10^{6}$ SOCS1-silenced DCimmunized group was significantly higher than that of the $2 \times 10^{6}$ DC/TRP2 and $2 \times 10^{6}$ DC-S1 mutant/TRP2- immunized groups $(\mathrm{p}<0.01)$. Therefore, up-regulated IL-12 likely led to reduced apoptosis in the $2 \times 10^{6}$ SOCS1-silenced DC/TRP2 immunized group. Decreased Fas-L mRNA expression in this group, along with no significant difference in Bcl-2 mRNA expression among the $1 \times 10^{6} \mathrm{DC} / \mathrm{TRP} 2,2 \times 10^{6} \mathrm{DC} / \mathrm{TRP} 2$ and $2 \times 10^{6}$ DC-S1/TRP2 groups, are a further indication that IL-12 up-regulation contributes to reduced apoptosis.

Previous studies have shown that IL-6 reduced the level of activation-induced cell death and the expression of Fas/Fas-L, yet it failed to inhibit IL-2 production (39). For this reason, IL-6 may be another important factor that prevented apoptosis in the $2 \times 10^{6}$ SOCS1-silenced DC-immunized group, since IL-6 production was significantly higher than in the $2 \times 10^{6}$ DC/TRP2-immunized group.

The secretion of IFN- $\gamma$ by $\mathrm{CD}^{+} \mathrm{T}$ cells has been shown to slow early tumor growth by inhibiting tumor angiogenesis $(32,33)$. IL-12 was also shown to exert anti-tumor immunity by inhibiting angiogenesis $(34,35,51)$. This is further supported by studies showing that endogenous IL-12 could trigger an anti-angiogenic response in B16 melanoma cells (52). In addition, studies have shown that IL-17, which is secreted mainly by Th- 17 cells, could promote angiogenesis in a variety of models and induce matrix metalloproteinases (MMPs), both of which can potentiate tumor growth $(31,40,53)$. The level of IL-17 production in $2 \times 10^{6}$ SOCS1-silenced DC/TRP2immunized mice was reduced by half in the $2 \times 10^{6} \mathrm{DC} / \mathrm{TRP} 2$ and $2 \times 10^{6}$ DC-S1 mutant/TRP2-immunized mice. It has been shown that IFN- $\gamma$ and IL-4 can down-regulate IL-17 production $(54,55)$ and both negatively regulate $\mathrm{T}$ helper cell production of IL-17 during the effector phase (54). Because of lower IL- 6 and TGF- $\beta$ production and higher IL-23 mRNA expression in $2 \times 10^{6}$ DC/TRP2-immunized mice, we deduced that higher levels of IL-4 (data not shown) and IFN- $\gamma$ in $2 \times 10^{6}$ DC-S1/TRP2-immunized mice suppressed IL-17 production by inhibiting IL-23 production. Therefore, in the $2 \times 10^{6}$ SOCS1-silenced DC-immunized mice, higher levels of IFN- $\gamma$ and IL-12p70, as well as lower IL-17 levels, could possibly have contributed to the enhanced anti-tumor immunity by inhibiting tumor growth. Inhibition of tumor growth, therefore, may play a partial role in breaking the immune tolerance.

As described above, activation-induced cell death plays a crucial role in immune tolerance induced by $2 \times 10^{6} \mathrm{DC} / \mathrm{TRP} 2$, while SOCS1-silencing could break it through elevated levels of IL-12p70 and IL-6. In addition, higher IFN- $\gamma$ and IL-12p70, as well as lower IL-17 production, which inhibit tumor angiogenesis, could also serve as an important factor for breaking the immune tolerance.

\section{Acknowledgments}

This work was supported in part by the Science and Technology Commission of Shanghai Municipality (project 04DZ14902) and Shanghai Leading Academic Discipline Project (T0206).

\section{References}

1. Steinman RM, Hawiger D and Nussenzweig MC: Tolerogenic dendritic cells. Annu Rev Immunol 21: 685-711, 2003.

2. Kubo M, Hanada T and Yoshimura A: Suppressors of cytokine signaling and immunity. Nat Immunol 4: 1169-1176, 2003.

3. Alexander WS and Hilton DJ: The role of suppressors of cytokine signaling (SOCS) proteins in regulation of the immune response. Annu Rev Immunol 22: 503-529, 2004.

4. Shen L, Evel-Kabler K, Strube R and Chen SY: Silencing of SOCS1 enhances antigen presentation by dendritic cells and antigen-specific anti-tumor immunity. Nat Biotechnol 22: 1546-1553, 2004

5. Woo SC, Kim GY, Lee CM, Moon DO, Kim HK, Lee TH, Moon YS, Park N C, Yoon MS, Lee KS and Park YM: The maturation of murine bone marrow-derived dendritic cells by tumor lysate uptake in vitro is not essential for cancer immunotherapy. Cancer Biol Ther 4: 1331-1335, 2005.

6. Boczkowski D, Nair SK, Snyder D and Gilboa E: Dendritic cells pulsed with RNA are potent antigen-presenting cells in vitro and in vivo. J Exp Med 184: 465-472, 1996.

7. Paglia P, Chiodoni C, Rodolfo M and Colombo MP: Murine dendritic cells loaded in vitro with soluble protein prime cytotoxic $\mathrm{T}$ lymphocytes against tumor antigen in vivo. J Exp Med 183: 317-322, 1996.

8. Ghiringhelli F, Menard C, Martin F and Zitvogel L: The role of regulatory $\mathrm{T}$ cells in the control of natural killer cells: relevance during tumor progression. Immunol Rev 214: 229-238, 2006.

9. Ashley DM, Faiola B, Nair S, Hale LP, Bigner DD and Gilboa E: Bone marrow-generated dendritic cells pulsed with tumor extracts or tumor RNA induce antitumor immunity against central nervous system tumors. J Exp Med 186: 1177-1182, 1997.

10. Nencioni A and Brossart P: Cellular immunotherapy with dendritic cells in cancer: current status. Stem Cells 22: 501-513, 2004.

11. Chen Y, Inobe J, Kuchroo VK, Baron JL, Janeway CA and Weiner HL: Oral tolerance in myelin basic protein T-cell receptor transgenic mice: suppression of autoimmune encephalomyelitis and dose-dependent induction of regulatory cells. Proc Natl Acad Sci USA 93: 388-391, 1996.

12. Friedman A and Weiner HL: Induction of anergy or active suppression following oral tolerance is determined by antigen dosage. Proc Natl Acad Sci USA 91: 6688-6692, 1994.

13. Melamed D and Friedman A: Direct evidence for anergy in $T$ lymphocytes tolerized by oral administration of ovalbumin. Eur J Immunol 23: 935-942, 1993.

14. Powell JD, Lerner CG and Schwartz RH: Inhibition of cell cycle progression by rapamycin induces $\mathrm{T}$ cell clonal anergy even in the presence of costimulation. J Immunol 162: 2775-2784, 1999.

15. Bohana-Kashtan O and Civin CI: Fas ligand as a tool for immunosuppression and generation of immune tolerance. Stem Cells 22: 908-924, 2004.

16. Green DR and Ferguson TA: The role of Fas ligand in immune privilege. Nat Rev Mol Cell Biol 2: 917-924, 2001.

17. Berger A, Piqueras B, Pages F, Tartour E, Cugnenc PH and Fridman WH: [Fas, fas ligand, immune tolerance, and cancer: implications in cancer of the colon]. Bull Cancer 85: 129-133, 1998.

18. Takahashi T, Tagami T, Yamazaki S, Uede T, Shimizu J, Sakaguchi N, Mak TW and Sakaguchi S: Immunologic selftolerance maintained by $\mathrm{CD} 25(+) \mathrm{CD} 4(+)$ regulatory $\mathrm{T}$ cells constitutively expressing cytotoxic $\mathrm{T}$ lymphocyte-associated antigen 4. J Exp Med 192: 303-310, 2000. 
19. Perez VL, van Parijs L, Biuckians A, Zheng XX, Strom TB and Abbas AK: Induction of peripheral $\mathrm{T}$ cell tolerance in vivo requires CTLA-4 engagement. Immunity 6: 411-417, 1997.

20. Walunas TL and Bluestone JA: CTLA-4 regulates tolerance induction and $\mathrm{T}$ cell differentiation in vivo. J Immunol 160: 3855-3860, 1998

21. Miyamoto K, Kingsley CI, Zhang X, Jabs C, Izikson L, Sobel RA, Weiner HL, Kuchroo VK and Sharpe AH: The ICOS molecule plays a crucial role in the development of mucosal tolerance. J Immunol 175: 7341-7347, 2005.

22. Lutz MB and Schuler G: Immature, semi-mature and fully mature dendritic cells: which signals induce tolerance or immunity? Trends Immunol 23: 445-449, 2002.

23. Rutella S, Danese S and Leone G: Tolerogenic dendritic cells: cytokine modulation comes of age. Blood 108: 1435-1440, 2006.

24. Jonuleit H, Schmitt E, Steinbrink K and Enk AH: Dendritic cells as a tool to induce anergic and regulatory T cells. Trends Immunol 22: 394-400, 2001.

25. Xiao BG, Huang YM and Link H: Tolerogenic dendritic cells: the ins and outs of outcome. J Immunother 29: 465-471, 2006.

26. Kurts C, Kosaka H, Carbone FR, Miller JF and Heath WR: Class I-restricted cross-presentation of exogenous self-antigens leads to deletion of autoreactive CD8(+) T cells. J Exp Med 186: 239-245, 1997.

27. Adler AJ, Marsh DW, Yochum GS, Guzzo JL, Nigam A, Nelson WG and Pardoll DM: CD4 ${ }^{+} \mathrm{T}$ cell tolerance to parenchymal self-antigens requires presentation by bone marrow-derived antigen-presenting cells. J Exp Med 187: 1555-1564, 1998.

28. Verhasselt V, Vosters O, Beuneu C, Nicaise C, Stordeur P and Goldman M: Induction of FOXP3-expressing regulatory CD4pos $\mathrm{T}$ cells by human mature autologous dendritic cells. Eur J Immunol 34: 762-772, 2004.

29. Tan JK and O'Neill HC: Maturation requirements for dendritic cells in T cell stimulation leading to tolerance versus immunity. J Leukoc Biol 78: 319-324, 2005.

30. Eichhorn ME, Kleespies A, Angele MK, Jauch KW and Bruns CJ: Angiogenesis in cancer: molecular mechanisms, clinical impact. Langenbecks Arch Surg 392: 371-379, 2007.

31. Numasaki M, Fukushi J, Ono M, Narula SK, Zavodny PJ, Kudo T, Robbins PD, Tahara H and Lotze MT: Interleukin-17 promotes angiogenesis and tumor growth. Blood 101: 2620-2627, 2003.

32. Qin Z and Blankenstein T: $\mathrm{CD}^{+} \mathrm{T}$ cell-mediated tumor rejection involves inhibition of angiogenesis that is dependent on IFN-gamma receptor expression by non-hematopoietic cells. Immunity 12: 677-686, 2000.

33. Beatty $G$ and Paterson Y: IFN-gamma-dependent inhibition of tumor angiogenesis by tumor-infiltrating $\mathrm{CD} 4^{+} \mathrm{T}$ cells requires tumor responsiveness to IFN-gamma. J Immunol 166: 2276-2282, 2001.

34. Brunda MJ, Luistro L, Warrier RR, Wright RB, Hubbard BR, Murphy M, Wolf SF and Gately MK: Antitumor and antimetastatic activity of interleukin 12 against murine tumors. $\mathrm{J}$ Exp Med 178: 1223-1230, 1993.

35. Shibata MA, Ito Y, Morimoto J, Kusakabe K, Yoshinaka R and Otsuki Y: In vivo electrogene transfer of interleukin-12 inhibits tumor growth and lymph node and lung metastases in mouse mammary carcinomas. J Gene Med 8: 335-352, 2006.

36. Yamazaki S, Iyoda T, Tarbell K, Olson K, Velinzon K, Inaba K and Steinman RM: Direct expansion of functional CD2 $5^{+} \mathrm{CD} 4^{+}$ regulatory $\mathrm{T}$ cells by antigen-processing dendritic cells. J Exp Med 198: 235-247, 2003.
37. Estaquier J, Idziorek T, Zou W, Emilie D, Farber CM, Bourez JM and Ameisen JC: T helper type 1/T helper type 2 cytokines and $\mathrm{T}$ cell death: preventive effect of interleukin 12 on activationinduced and CD95 (FAS/APO-1)-mediated apoptosis of CD4 ${ }^{+}$ $\mathrm{T}$ cells from human immunodeficiency virus-infected persons. $\mathrm{J}$ Exp Med 182: 1759-1767, 1995.

38. Lee SW, Park Y, Yoo JK, Choi SY and Sung YC: Inhibition of TCR-induced CD8 T cell death by IL-12: regulation of Fas ligand and cellular FLIP expression and caspase activation by IL-12. J Immunol 170: 2456-2460, 2003.

39. Ayroldi E, Zollo O, Cannarile L, Grohmann U, Delfino DV and Riccardi C: Interleukin-6 (IL-6) prevents activation-induced cell death: IL-2-independent inhibition of Fas/fasL expression and cell death. Blood 92: 4212-4219, 1998.

40. Numasaki M, Watanabe M, Suzuki T, Takahashi H, Nakamura A, McAllister F, Hishinuma T, Goto J, Lotze MT, Kolls JK and Sasaki H: IL-17 enhances the net angiogenic activity and in vivo growth of human non-small cell lung cancer in SCID mice through promoting CXCR-2-dependent angiogenesis. J Immunol 175: 6177-6189, 2005.

41. Bettelli E, Oukka M and Kuchroo VK: T(H)-17 cells in the circle of immunity and autoimmunity. Nat Immunol 8: 345-350, 2007.

42. Ohashi PS and De Franco AL: Making and breaking tolerance. Curr Opin Immunol 14: 744-759, 2002.

43. Kobayashi $\mathrm{T}$ and Yoshimura A: Keeping DCs awake by putting SOCS1 to sleep. Trends Immunol 26: 177-179, 2005.

44. Green DR, Droin N and Pinkoski M: Activation-induced cell death in T cells. Immunol Rev 193: 70-81, 2003.

45. Vieweg J and Jackson A: Modulation of antitumor responses by dendritic cells. Springer Semin Immunopathol 26: 329-341, 2005.

46. Ostrand-Rosenberg S: CD4 ${ }^{+} \mathrm{T}$ lymphocytes: a critical component of antitumor immunity. Cancer Invest 23: 413-419, 2005.

47. Shiku H: Importance of $\mathrm{CD}^{+}$helper T-cells in antitumor immunity. Int J Hematol 77: 435-438, 2003.

48. Shustov A, Nguyen P, Finkelman F, Elkon KB and Via CS: Differential expression of Fas and Fas ligand in acute and chronic graft-versus-host disease: up-regulation of Fas and Fas ligand requires $\mathrm{CD}^{+} \mathrm{T}$ cell activation and IFN-gamma production. J Immunol 161: 2848-2855, 1998.

49. Roth E and Pircher H: IFN-gamma promotes Fas ligand- and perforin-mediated liver cell destruction by cytotoxic CD8 T cells. J Immunol 172: 1588-1594, 2004.

50. Marth T, Zeitz M, Ludviksson BR, Strober W and Kelsall BL: Extinction of IL-12 signaling promotes Fas-mediated apoptosis of antigen-specific T cells. J Immunol 162: 7233-7240, 1999.

51. Minuzzo S, Moserle L, Indraccolo S and Amadori A: Angiogenesis meets immunology: cytokine gene therapy of cancer Mol Aspects Med 28: 59-86, 2007.

52. Airoldi I, Di Carlo E, Cocco C, Taverniti G, D'Antuono T, Ognio E, Watanabe M, Ribatti D and Pistoia V: Endogenous IL-12 triggers an antiangiogenic program in melanoma cells. Proc Natl Acad Sci USA 104: 3996-4001, 2007.

53. Langowski JL, Kastelein RA and Oft M: Swords into plowshares: IL-23 repurposes tumor immune surveillance. Trends Immunol 28: 207-212, 2007.

54. Park H, Li Z, Yang XO, Chang SH, Nurieva R, Wang YH, Wang Y, Hood L, Zhu Z, Tian Q and Dong C: A distinct lineage of CD 4 T cells regulates tissue inflammation by producing interleukin 17. Nat Immunol 6: 1133-1141, 2005.

55. Harrington LE, Hatton RD, Mangan PR, Turner H, Murphy TL, Murphy KM and Weaver CT: Interleukin 17-producing CD4 ${ }^{+}$ effector $\mathrm{T}$ cells develop via a lineage distinct from the T helper type 1 and 2 lineages. Nat Immunol 6: 1123-1132, 2005. 